\title{
Anti-diabetic Effect of Myrtenal on Plasma and Tissue Glycoproteins Components in STZ Induced Experimental Diabetic Rats
}

\author{
Leelavinothan Pari ${ }^{1,2, *}$, Ayyasamy Rathinam ${ }^{1}$ \\ ${ }^{1}$ Phytopharmacology and Molecular Biology Research Laboratory Annamalai University, Annamalainagar Tamilnadu, India \\ ${ }^{2}$ Department of Biochemistry \& Biotechnology Faculty of Science, Annamalai University, Annmalainagar, Tamilnadu, India
}

\section{Email address:}

parinarayana@gmail.com (L. Pari)

\section{To cite this article:}

Leelavinothan Pari, Ayyasamy Rathinam. Anti-diabetic Effect of Myrtenal on Plasma and Tissue Glycoproteins Components in STZ Induced Experimental Diabetic Rats. Journal of Diseases and Medicinal Plants. Special Issue: Medicinal Food Plants.

Vol. 2, No. 1-1, 2016, pp. 11-16. doi: 10.11648/j.jdmp.s.2016020101.12

\begin{abstract}
The aim of present study was to evaluate the effect of myrtenal, a monoterpene on plasma and tissues glycoprotein components in streptozotocin-induced diabetic rats. Diabetes was induced in overnight fasted experimental rats by a single intraperitoneal injection of streptozotocin (STZ; $40 \mathrm{mg} / \mathrm{kg}$ body weight) dissolved in $0.1 \mathrm{M}$ citrate buffer at $\mathrm{pH} 4.5$. STZinjected animals were given $20 \%$ glucose solution for $24 \mathrm{~h}$ to prevent initial drug-induced hypoglycemia mortality. The levels of plasma glucose, plasma and tissues glycoproteins such as hexose, hexosamine, fucose and sialic acid were significantly increased whereas plasma insulin levels were significantly decreased in diabetic rats. On oral administration myrtenal (80 $\mathrm{mg} / \mathrm{kg}$ b.w.) once daily to diabetic rats for the period of 28 days brought back the levels of plasma and tissues glycoprotein components. Based on the present study, we propose that myrtenal possesses significant protective effect on glycoprotein metabolism.
\end{abstract}

Keywords: Myrtenal, Glycoproteins, Wistar Rat, Streptozotocin, Hyperglycemia

\section{Introduction}

Diabetes mellitus (DM) is one of the most considerable chronic diseases associated with defects in insulin secretion, insulin action, or both, resulting in impaired function in carbohydrate, lipid and protein metabolism. Moreover, chronic hyperglycemia leads to the pathogenesis of macrovascular and microvascular complications [1].

High glucose/hyperglyceamia (and also other sugars) activates the polyol pathway, increased formation of AGEs (advanced glycation end products) along with the expression of the receptor for AGEs, activation of protein kinase C (PKC) isoforms and increased activity of the hexosamine pathway were reported to be important [2]. Glycoproteins are carbohydrate linked protein macromoleculesfound in the cell surface, which form the principal componentof animal cells. Hexose, hexosamine and sialic acid are the basic components of the glycoproteins. They play an important role in membrane transport, cell differentiation and recognition, the adhesion of macromolecules to the cell surface and the secretion and absorption of macromolecules [3]. Impaired metabolism of glycoproteins play a major role in the pathogenesis of diabetes mellitus [4]. It has been reported that alterations occur in the concentrations of various glycoproteins in human diabetes [5]. The raised levels of glycoproteins in diabetics may also be an indicator of angiopathic complications [6]. Several workers have suggested that elevated levels of glycoproteins in plasma, liver and kidney tissues in the diabetic condition could be a consequence of impaired carbohydrate metabolism. Insulin deficiency and high levels of plasma glucose in the diabetic condition may result in an increased synthesis of glycoproteins [7].

Several oral therapeutic agents are the foremost option treatments of type $2 \mathrm{DM}$. The rationale of these oral hypoglycemic agents is to ameliorate the underlying metabolic disorder, associated with inadequate insulin secretion and insulin resistance. However, they have limited efficacy and occasionally produced severe side effects such as weight gain, hypoglycemia, gastrointestinal disturbances, liver injury and heart failure [8]. Consequently, alternative 
medicines and natural therapies have received renewed attention in recent decades. A number of species of medicinal plants have been described in scientific and literature as having hypoglycemic action. The plant kingdom is a wide field to search for new drugs and biologically active compounds that have perceived effectiveness, minimal side effects or no side effect in clinical practice [9].

In recent years, terpenoids are extensively studied upon various diseases including diabetes. It has been documented to posses pharmacological effects against various diseases. Myrtenal is a monoterpene found in Mint, amongst other traditional herbs. It has been reported to possess various biological activities such as antioxidant, anticancer, cyclooxygenase-inhibitor and immunostimulant effects [1012]. Recently, we have found that myrtenal has the antidiabetic and hepatoprotective effects in experimental diabetic rats [13]. But, there is insufficient evidence in the literature to make a definitive conclusion about the effects of myrtenal on glycoproteins level. Considering these facts and lack of efficient information about pharmacological effects of myrtenal role in diabetes, we have investigated the glycoproteins level in STZ-induced experimental diabetic rats.

\section{Material and Methods}

\subsection{Animals}

Adult male albino Wistar rats (180-200 g) were obtained from the Central Animal House, Department of Experimental Medicine, Rajah Muthiah Medical College and Hospital, Annamalai University and maintained at a constant temperature $\left(25 \pm 1^{\circ} \mathrm{C}\right)$ on a $12 \mathrm{~h}$ light $/ 12 \mathrm{~h}$ dark cycle with feeds (National Institute for Nutrition, Hyderabad, India) and water was provided ad libitum. The experimental protocol was approved by the animal ethics committee of Rajah Muthiah Medical College and Hospital (Reg. No. 160/1999/CPCSEA, Proposal number: 1000), Annamalai University.

\subsection{Chemicals}

Myrtenal and Streptozotocin (STZ) were purchased from Sigma-Aldrich (St. Louis, MO, USA). All other chemicals used in this study were of analytical grade obtained from Merck and Hi Media, India.

\subsection{Induction of Diabetes in Rats}

Diabetes mellitus was induced in overnight fasted experimental rats by a single intraperitoneal injection (ip) of STZ $(40 \mathrm{mg} / \mathrm{kg} \mathrm{bw})$ dissolved in $0.1 \mathrm{M}$ citrate buffer at $\mathrm{pH}$ 4.5. STZ injected animals were given $20 \%$ glucose solution for $24 \mathrm{~h}$ to prevent initial drug-induced hypoglycemia mortality. STZ injected animals exhibited hyperglycemia within a few days. Diabetic condition rats were confirmed by measuring the elevated fasting plasma glucose (by glucose oxidase method) $72 \mathrm{~h}$ after STZ injection. The rats with fasting blood glucose above $250 \mathrm{mg} / \mathrm{dL}$ were considered to be diabetic and used for the experiment.

\subsection{Treatment Schedule}

The rats were divided into four groups, each comprising of six rats (24 rats). Myrtenal was dissolved in $1 \mathrm{~mL}$ of corn oil and administered orally to the experimental rats using an intragastric tube daily for a period of 28 days [13].

Group I: normal control rats.

Group II: normal + myrtenal (myt) $(80 \mathrm{mg} / \mathrm{kg} \mathrm{bw} /$ day).

Group III: diabetic control rats.

Group IV: diabetic + myrtenal (myt) $(80 \mathrm{mg} / \mathrm{kg}$ bw/day).

At the end of the experimental period, all the animals were fasted overnight, anaesthetized and sacrificed by cervical dislocation. Blood samples were collected in tubes containing potassium oxalate and sodium fluoride $(3: 1)$ mixture for the estimation of fasting plasma glucose. The liver and kidney were dissected out, washed in ice-cold saline and stored at $80^{\circ} \mathrm{C}$ until used. The liver and kidney were weighed and $10 \%$ tissue homogenate was prepared with $0.1 \mathrm{M}$ Tris- $\mathrm{HCl}$ buffer, $\mathrm{pH}$ 7.4. After centrifugation, the clear supernatant was obtained and used for biochemical assays.

\subsection{Plasma Glucose and Insulin Assay}

Fasting plasma glucose was estimated by diagnostic kits (Agappe Diagnostic Pvt. Ltd., Kerala, India). Insulin content was analyzed multi-well plate reader using the rat insulin ELISA kit, Mercodia, Uppsala, Sweden, according to manufacturer instructions.

\subsection{Extraction of Glycoproteins}

To $0.1 \mathrm{~mL}$ of plasma, $5.0 \mathrm{~mL}$ of methanol was added, mixed well and centrifuged for $10 \mathrm{~min}$ at $3000 \times \mathrm{g}$. The supernatant was decanted and the precipitate was again washed with $5.0 \mathrm{~mL}$ of $95 \%$ ethanol, recentrifuged and the supernatant was decanted to obtain the precipitate of glycoproteins. This was used for the estimation of hexose and hexosamine. For extraction of glycoproteins from the tissues, a known weight of the tissue was homogenized in $7.0 \mathrm{~mL}$ of methanol. The contents were filtered and homogenized with $14.0 \mathrm{~mL}$ of chloroform. This was filtered and the residue was successively homogenized in chloroform-methanol $(2: 1 \mathrm{v} / \mathrm{v})$ and each time the extract was filtered. The residue (defatted tissues) was obtained and the filtrate decanted. A weighed amount of defatted tissue was suspended in $3.0 \mathrm{~mL}$ of $2 \mathrm{~N}$ $\mathrm{HCl}$ and heated at $90^{\circ} \mathrm{C}$ for $4 \mathrm{~h}$. The sample was cooled and neutralized with $3.0 \mathrm{~mL}$ of $2 \mathrm{~N} \mathrm{NaOH}$. Aliquots from this were used for estimation of fucose, hexose, hexosamine and sialic acid.

\subsection{Determination of Glycoproteins}

The plasma and tissue hexose content were estimated by the method of Niebes [14], sialic acid in plasma and tissues were estimated by the method of Warren [15] and hexosamine by the method of Wagner [16]. Fucose was estimated by the method of Dische and Shettles [17] respectively. 


\subsection{Statistical Analysis}

Data are presented as means \pm standard deviation $(\mathrm{SD})$ and were subjected to statistical significance was evaluated by one way analysis of variance (ANOVA) using statistical package for the social sciences (SPSS) Version 17.0 (SPSS, Cary, NC, USA) and the individual comparisons were obtained by Duncan's multiple range test (DMRT). Values were considered statistically significant at $\mathrm{p}<0.05$.

\section{Results}

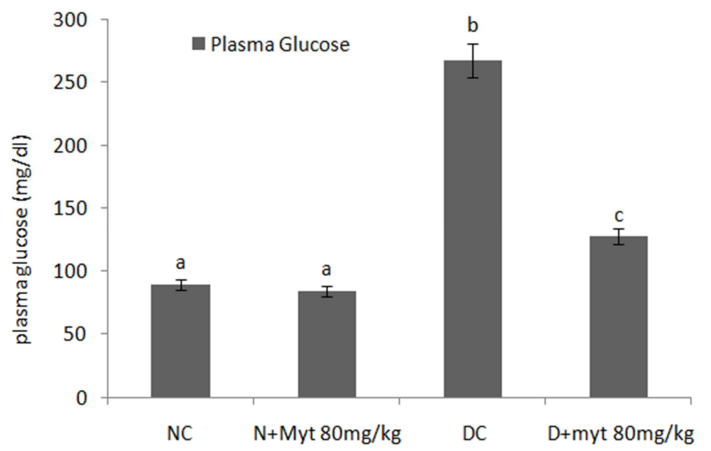

Figure 1. Effect of myrtenal on plasma glucose levels in normal and experimental rats.

Values in each group are represented as means $\pm \mathrm{SD}$ for 6 rats in each group Values are not sharing a common superscript letter (a-c) differ significantly at $\mathrm{p}<0.05$ (DMRT).

Figure 1 shows the levels of plasma glucose in normal control and experimental rats. Diabetic control rats showed significant $(p<0.05)$ increase in the levels of plasma glucose as compared with normal control rats. However, after treatment with myrtenal $(80 \mathrm{mg} / \mathrm{kg})$ significantly reduced the levels of plasma glucose in diabetic rats as compared with diabetic control rats.

Table 1 shows the levels of plasma insulin. Diabetic control rats showed significant $(p<0.05)$ decrease in the levels of plasma insulin as compared with normal control rats. Treatment with myrtenal $(80 \mathrm{mg} / \mathrm{kg})$ to diabetic rats significant $(\mathrm{p}<0.05)$ increases in plasma insulin level as compared with diabetic control rats.

Table 2 shows the changes in the level of plasma glycoproteins of control and experimental rats. There was a significant $(p<0.05)$ increase of plasma glycoproteins in diabetic rats. Oral administration of myrtenal $(80 \mathrm{mg} / \mathrm{kg})$ significantly $(p<0.05)$ decreased the level of plasma glycoproteins.

Tables 3 and 4 represent the levels of liver and kidney glycoprotein of control and experimental rats. The levels of glycoprotein containing hexose, hexosamine, fucose and silalic acid were significantly $(\mathrm{p}<0.05)$ increased. Oral administration of myrtenal $(80 \mathrm{mg} / \mathrm{kg})$ significantly decreased these changes in the glycoproteins levels in the liver and kidneys of diabetic rats.

Table 1. Effect of myrtenal on plasma insulin levels in normal and experimental rats.

\begin{tabular}{ll}
\hline Groups & Plasma Insulin $(\boldsymbol{\mu U} / \mathbf{m l})$ \\
\hline Normal control & $16.0 \pm 1.08^{\mathrm{a}}$ \\
Normal + Myrtenal $(80 \mathrm{mg} / \mathrm{kg})$ & $17.95 \pm 1.63^{\mathrm{a}}$ \\
Diabetic control & $9.80 \pm 0.38^{\mathrm{b}}$ \\
Diabetic + Myrtenal $(80 \mathrm{mg} / \mathrm{kg})$ & $13.7 \pm 1.15^{\mathrm{c}}$ \\
Values in each group are represented as means \pm SD for 6 rats in each \\
group. Values are not sharing a common superscript letter $(\mathrm{a}-\mathrm{c})$ differ \\
significantly at $\mathrm{p}<0.05(\mathrm{DMRT})$.
\end{tabular}

Table 2. Effect of myrtenal on plasma glycoproteins levels $(\mathrm{mg} / \mathrm{dl})$ in normal and experimental rats.

\begin{tabular}{|c|c|c|c|c|}
\hline Groups & Hexose & Hexosamine & Fucose & Sialic acid \\
\hline Normal control & $88.62 \pm 6.08^{\mathrm{a}}$ & $68.43 \pm 3.32^{\mathrm{a}}$ & $32.24 \pm 2.31^{\mathrm{a}}$ & $53.75 \pm 3.04^{\mathrm{a}}$ \\
\hline Normal + Myrtenal $(80 \mathrm{mg} / \mathrm{kg})$ & $86.91 \pm 5.53^{\mathrm{a}}$ & $68.10 \pm 3.65^{\mathrm{a}}$ & $31.63 \pm 2.65^{\mathrm{a}}$ & $52.43 \pm 2.65^{\mathrm{a}}$ \\
\hline Diabetic control & $154.47 \pm 11.38^{b}$ & $97.21 \pm 9.18^{b}$ & $46.10 \pm 3.65^{b}$ & $72.45 \pm 7.08^{b}$ \\
\hline Diabetic + Myrtenal $(80 \mathrm{mg} / \mathrm{kg})$ & $110.31 \pm 7.85^{\mathrm{c}}$ & $87.57 \pm 5.97^{\mathrm{c}}$ & $39.46 \pm 2.73^{c}$ & $63.10 \pm 4.53^{c}$ \\
\hline
\end{tabular}

Table 3. Effect of myrtenal on liver glycoproteins levels ( $\mathrm{mg} / \mathrm{g}$ defatted tissue) in normal and experimental rats.

\begin{tabular}{|c|c|c|c|c|}
\hline Groups & Hexose & Hexosamine & Fucose & Sialic acid \\
\hline Normal control & $28.36 \pm 1.55^{\mathrm{a}}$ & $10.82 \pm 0.55^{\mathrm{a}}$ & $14.82 \pm 1.22^{\mathrm{a}}$ & $9.26 \pm 0.46^{\mathrm{a}}$ \\
\hline Normal + Myrtenal $(80 \mathrm{mg} / \mathrm{kg})$ & $27.84 \pm 1.32^{\mathrm{a}}$ & $10.30 \pm 0.44^{\mathrm{a}}$ & $15.10 \pm 1.43^{\mathrm{a}}$ & $9.40 \pm 0.51^{\mathrm{a}}$ \\
\hline Diabetic control & $48.79 \pm 3.98^{b}$ & $19.60 \pm 1.10^{b}$ & $31.24 \pm 3.24^{\mathrm{b}}$ & $4.25 \pm 0.44^{\mathrm{b}}$ \\
\hline Diabetic + Myrtenal $(80 \mathrm{mg} / \mathrm{kg})$ & $37.65 \pm 2.87^{\mathrm{c}}$ & $16.30 \pm 0.99^{c}$ & $25.40 \pm 2.48^{c}$ & $7.40 \pm 0.68^{c}$ \\
\hline
\end{tabular}

Table 4. Effect of myrtenal on kidney glycoproteins levels ( $\mathrm{mg} / \mathrm{g}$ defatted tissue) in normal and experimental rats.

\begin{tabular}{|c|c|c|c|c|}
\hline Groups & Hexose & Hexosamine & Fucose & Sialic acid \\
\hline Normal control & $25.16 \pm 2.54^{\mathrm{a}}$ & $13.93 \pm 0.83^{\mathrm{a}}$ & $13.86 \pm 0.89^{\mathrm{a}}$ & $8.95 \pm 0.81^{\mathrm{a}}$ \\
\hline Normal + Myrtenal $(80 \mathrm{mg} / \mathrm{kg})$ & $24.75 \pm 2.35^{\mathrm{a}}$ & $13.30 \pm 0.88^{\mathrm{a}}$ & $13.58 \pm 0.99^{\mathrm{a}}$ & $9.30 \pm 0.95^{\mathrm{a}}$ \\
\hline Diabetic control & $45.10 \pm 4.64^{b}$ & $28.78 \pm 2.7^{b}$ & $32.92 \pm 3.43^{b}$ & $4.79 \pm 0.49^{b}$ \\
\hline Diabetic + Myrtenal $(80 \mathrm{mg} / \mathrm{kg})$ & $34.86 \pm 3.44^{\mathrm{c}}$ & $19.93 \pm 1.6^{\mathrm{c}}$ & $23.67 \pm 1.54^{\mathrm{c}}$ & $7.64 \pm 0.74^{\mathrm{c}}$ \\
\hline
\end{tabular}




\section{Discussion}

Type 2 diabetes is one of the most common chronic and progressive diseases and is a consequence of number of defects including impaired insulin secretion by the pancreatic cells, resistance of peripheral tissues to the effect of insulin and augmented hepaticg glucose production. Effective control of blood glucose level by increasing the secretion of the insulin granules and regeneration of beta cells in the pancreas is a key step in preventing diabetic complications and improving the quality of life in type 2 diabetic patients [18]. In the present study, STZ induced diabetic animal showed increased plasma glucose and decreased insulin levels were observed. Oral administration of myrtenal improved the glyceamic control. Myrtenal improved the insulin secretion from remnant $\beta$-cells, which in turn enhance glucose utilization by peripheral tissues of diabetic animals either by promoting glucose uptake and metabolism, or by inhibiting hepatic gluconeogenesis and decreased blood glucose levels [13]. In previous study, the terpenoids have produced same effect in diabetic condition; the role of terpenoids in ameliorating hyperglycaemia could be by potentiation of release of insulin from $\beta$ cells of islets $[19,20]$.

Glycoproteins are carbohydrate linked protein macromolecules found in the cell surface, which form the principle components of animal cells. They play vital role in membrane transport, cell differentiation and recognition, the adhesion of macromolecules to cell surface and the excretion and absorption of macromolecules [21]. Prolonged elevation of blood glucose in diabetes may result in structural and functional alteration of both circulating and membrane bound proteins [22]. Alterations in the diabetic state of the composition of the carbohydrate components of glycoproteins, especially serum glyloproteins and glycoproteins of the capillary basement membrane have been reported [23].

Increased glycosylation of various proteins in diabetic condition have been reported [24]. In ours study, we have noted the elevated levels of hexose, hexosamine, fucose and sialic acid in the plasma and tissues (liver and kidney) of streptozotocin induced diabetic rats. The increase in plasma glycoprotein components has been linked with the severity and period of diabetes. The secretion or shedding from cell membrane glycol conjugates into the circulation leads to the elevation of plasma glycoprotein components [25]. This is due to the depressed utilization of glucose by insulin dependent pathways leads to increase the formation of hexose, hexosamine, sialic acid and fucose for the accumulation of glycoproteins [26]. Administration of myrtenal to diabetic rats decreased plasma the levels of glycoprotein components. This could be due to the decreased hyperglycemic state with increased levels of plasma insulin in diabetic rats.

The liver is principally responsible for producing a abundance of glycoproteins present in blood. The elevated levels of plasma glycoproteins in diabetic condition could be a consequence of abnormal carbohydrate metabolism [27]. Hexose, hexosamine and sialic acid are the fundamental components of the glycosaminoglycans and glycoproteins. Increased depositions of these components have been observed in the liver of STZ-induced diabetic rats [3, 28]. Oral administration of myrtenal to diabetic rats decreased the levels of glycoprotein components in liver.

In hyperglycemia, free amino groups of proteins react slowly with the carbonyl groups of reducing sugars such as glucose, to yield a schiff-base intermediate and these schiffbase intermediates undergo Amadori rearrangement to stable ketoamine derivative (fucosamine) [29]. Fucose is a member of the group of 8 essential sugars the body requires for optimal function of cell-to-cell communication and its metabolism shows to be altered in various diseases such as diabetes mellitus [30]. Elevated levels of fucose in experimental diabetes were reported by researchers [31, 32].

Renal disease is one of the most common and severe complications in diabetes [33]. Diabetes mellitus affects the kidney and is the leading cause of diabetic nephropathy. In addition to prominent role played by factors such as oxidative stress, abnormal lipid metabolism and renal accumulation lipids and others, abnormal glycoprotein metabolism have also been proposed to play a pivotal role in the pathogenesis of diabetic nephropathy [34]. The excess availability of glucose in the hyperglycemic state accelerates the synthesis of basement membrane components, i.e., glycoproteins [26] and this leads to the thickening of capillary basement membrane [35]. This is due to depressed utilization of glucose by insulin-dependent pathway, thereby enhancing the formation of hexose and hexosamine for the accumulation of glycoproteins [7]. The luminal surface of epithelial cells in kidney tubules is also lined with a thick carbohydrate rich glycoprotein layer [3]. Stimulation of kidney protein synthesis may contribute to explain the increase in the synthesis of glycoproteins (and therefore of the basement membrane) as well as the renal hypertrophy that occurs early in diabetes [36]. Treatment with iridoid glucoside reversed the alterations induced in levels of hexoses, hexosamine, fucose and sialic acid in the kidneys of diabetic rats. This may be due to the activation of glucose transport mechanism and also alters insulin binding receptor specificity [37].

In conclusion, our study showed that myrtenal decreased hyperglycemia in diabetic rats which is responsible for the decrease of glycoproteins in plasma, liver and kidney. Myrtenal may have beneficial role in diabetic rats which may be due to the enhancement of insulin. However, additional studies are in progress to emphasize the molecular action of myrtenal in diabetic rats.

\section{Acknowledgement}

We thank the University Grants Commission (UGC), New Delhi, India for funding support in the form of research 
fellow under Research Fellowship in Science for Meritorious Students (RFSMS) Scheme (F.25-1/201314(BSR)/7/10/2007) to Mr. A. Rathinam.

\section{References}

[1] Ghoul JE, Smiri M, Ghrab S, Boughattas NA, Ben-Attia M. Antihyperglycemic, antihyperlipidemic and antioxidant activities of traditional aqueous extract of Zygophyllum album in streptozotocin diabetic mice. Pathophysiol 2012; 19: 35-42.

[2] Giacco F, Brownlee M. Oxidative stress and diabetic complications Circulation research, 2010; 107: 1058-1070.

[3] Mittal N, Keaur J, Mahmood A. Changes in tubular membrane glycosylation in diabetic insulin and thyroxin treated rat kidneys. Ind J Exp Biol 1996; 34: 782-785.

[4] Knecht KT, Bradford BU, Mason RP, Thurman RG. In vivo formation of a free radicals metabolite of ethanol. Mol Pharmacol 1990; 38: 26-30.

[5] Sharma C, Dalferes FR, Radhakrishnamurthy B, De-Paolo CJ, Berenson GS. Hepatic glycoprotein synthesis in streptozotocin diabetic rats. Biochem Int 1987; 15-19.

[6] Konukoglu D, Serin O, Akcay T, Hatemi H. Relationship between diabetic angiopathic complications and serum total and lipid associated sialic acid concentrations. Med Sci Res 1999; 27: 53-55.

[7] Patti ME, Virkamaki A, Landaker EJ, Kahn CR, Yki-Jarvinen $\mathrm{H}$. Activation of the hexosamine pathway by glucosamine in vivo induces insulin resistance of early post receptor insulin signaling events in skeletal muscle. Diabetes 1999; 48: 15621571 .

[8] Sundaram R, Naresha R, Shanthi P, Sachdanandam P. Efficacy of 20-OH-ecdysone on hepatic key enzymes of carbohydrate metabolism in streptozotocin induced diabetic rats. Phytomedicine 2012; 19: 725-729.

[9] Tang L, Wei W, Chen L, Liu S. Effects of berberine on diabetes induced by alloxan and a high-fat/high-cholesterol diet in rats J. Ethnopharmacol 2006; 108: 109-115.

[10] Verges B. Lipid modification in type 2 diabetes: the role of LDL and HDL. Fundam Clin Pharmacol 2009; 23: 681-685.

[11] Marica Lindmark H, Dan I, Tomas V, Irena V, Hans-Erik H, Kristina S. Transformation of terpenes using a Picea abies suspension culture. J Biotechnol 2004; 107: 173-184.

[12] Vibha JB, Choudhary K, Mangal Singh, Rathore MS, Shekhawat NS. A study on pharmacokinetics and therapeutic efficacy of Glycyrrhiza glabra a Miracle Medicinal Herb. Bot Res Int 2009; 2: 157-163.

[13] Rathinam A, Pari L, Chandramohan R, Sheikh BA. Histopathological findings of the pancreas, liver, and carbohydrate metabolizing enzymes in STZ-induced diabetic rats improved by administration of myrtenal. J Physiol Biochem 2014; 70: 935-946.

[14] Niebes P. Determination of enzymes and degradation products of glycosaminoglycan metabolism in the serum of healthy and varicose subjects. Clin Chim Acta1972; 42: 399-408.

[15] Warren L. The thiobarbituric acid assay of sialic acids. J Biol
Chem 1959; 234: 1971-1975.

[16] Warren L. The thiobarbituric acid assay of sialic acids. J Biol Chem 1959; 234: 1971-1975.

[17] Dische Z, Shettles LB. A specific color reaction of methylpentoses and a spectrophotometric micro method for their determination. J Biol Chem1948; 175: 595-603.

[18] Shulman GI. Cellular mechanisms of insulin resistance. J Clin Invest 2000; 106: 171-6.

[19] Peng CH, Ker YB, Weng CF, Peng CC, Huang CN, Lin LY et al. Insulin secretagogue bioactivity of finger citron fruit (Citrus medicaL. var. Sarcodactylis Hort, Rutaceae). J Agric Food Chem 2009; 57: 8812-9.

[20] Jeppesen PB, Gregersen S, Poulsen CR, Hermansen K. Stevioside acts directly on pancreatic beta-cells to secrete insulin: actions independent of cyclic adenosine monophosphate and adenosine triphosphate-sensitive $\mathrm{K}+$ channel activity. Metabolism 2000; 49: 208-14.

[21] Parillo F, Arias MP, Supplizi AV. Glycoprofile of the different cell types present in the mucosa of the horse guttural pouches. Tissue Cell 2009; 41: 257-265.

[22] Ciftci G, Yarim GF. Evaluation of IGF-I levels and serum protein profiles of diabetic cats and dogs. J Vet Sci 2011; 12: 325-331.

[23] Buse MG. Hexosamines, insulin resistance, and the complications of diabetes: current status. Am J Physiol Endocrinol Metab 2006; 290:1-8.

[24] Rahman MA, Zafar G, Shera AS. Changes in glycosylated proteins in long term complications of diabetes mellitus. Biomed Pharmacother 1990; 44: 229-234.

[25] Berenson GS, Radhakrishnamurthy Dalferes ER. Connective tissue macromolecular changes in rats with experimentally induced diabetes and hyperinsulinism. Diabetes 1972; 21: 733-743.

[26] Spiro RG, Spiro MJ. Effect of diabetes on the biosynthesis of the renal glomerular basement membrane. Studies on the glycosyl transferase. Diabetes 1971; 20: 641-648.

[27] Guillot R, Kassab JP, Ogneva U, Andre J, Durussel JJ, Hadjiisky P, Peyroux J, Sternberg M. Relation between pancreatic islet cellular infiltration and plasma fibrinogen or [alpha] 1-acid glycoprotein levels in spontaneously and streptozotocin-diabetic rats: an increase in these protein levels is not necessary for inducing microcirculatory erythrocyte velocity alteration. Pancreas 1994; 9: 336-343.

[28] Robinson KA, Weinstein MP, Lindenmayer GE, Byse MG. Effects of diabetes and hyperglycemia on the hexosamine synthesis pathway in rat muscle and liver. Diabetes 44, 14381446.

[29] Bucala, R. Advanced glycosylation end products and diabetic vascular disease, in Keaney JF Jr.(Edn). Oxidative stress and vascular disease. Kluwer academic publishers Dordrecht. 1999; pp. 287-303.

[30] Mondoa S, Emil, Kitei M. 2001. The new healing science of glyconutrients, in sugars that heal. Ballantine Publishing, New York.

[31] Prakasam A, Sethupathy S, Pugalendi KV. Influence of Casearia esculenta root extract on glycoprotein components in streptozotocin diabetic rats. Pharmazie 2005; 60: 229-232. 
[32] Latha M, Pari L. Effect of an aqueous extract of Scoparia dulcis on plasma and tissue glycoproteins in streptozotocin induced diabetic rats. Pharmazie 2005; 60: 151-154.

[33] Shanmugasundram ERB, Gopinath KL, Shanmugasundram, KR, Rajendran VM. Possible regeneration of islets of Langerhans in streptozotocin diabetic rats given Gymnema sylvestre leaf extract. J Ethnopharmacol 1990; 30: 265-279.

[34] Kimmelsteil P, Wilson C. Inter capillary lesion in the glomeruli of the kidney. Am J Pathol 1936; 12: 83-105.

[35] Rasch R, Torffucit O, Bachmann S, Jensen PK, Jacobsen NO. Glycoprotein in streptozotocin diabetic rats: a study of kidney in situ hybridization, immunohistochemistry and urinary excretion. Diabetologia 1955; 32: 525-535.

[36] Camerini Davalos RA, Velasco CA, Reddi AS 1990. Metabolism of glomerular basement membrane in diabetes. In: Belfiore, F., Molinatti, G.M., Reaven, G.M. (Eds.), Frontiers in Diabetes. Karger, Basel, Switzerland, pp. 61-77.

[37] Marshall S, Bacote V, Traxinger RR. Discovery of metabolic pathway mediating glucose induced desensitization of glucose transport system: role of hexosamine biosynthesis in the induction of insulin resistance. J Biol Chem 1991; 266: 47064712 . 